\title{
The Role and the Importance of the Greek SMEs in the Production of Innovation
}

\author{
Maria Markatou
}

National and Kapodistrian University of Athens, Technological Education Institute of Larissa, Larissa, Greece

\begin{abstract}
Innovation is widely recognized as a key factor in the economic development of nations. Innovation is also essential for the competitiveness of firms. Its importance is intensified by factors like the increased global competition, the decreased product lifecycles and the rapidly changing consumer demands. Large firms play a key role in innovation but this doesn't mean that there is no place for SMEs. In the last years the environment for innovation has changed. The importance of SMEs to the innovation process has increased. The increasing incomes, the more "niched" market demand and the changing technologies have reduced the structural disadvantages of SMEs firm size.

In this paper we examine the role of the Greek SMEs in innovation generation. Our analysis shows that small firms are the main owners of the granted patents in Greece. So, firms that employ up to 50 employees account for $57.83 \%$ of our sample, while the share of large firms (more than 500 employees) is $6.02 \%$. Most of these firms are engaged in the economic activities of machine tools, metal and plastic products, chemical substances and wholesale. The Greek SMEs have a medium age and are characterized by different levels of exports, selling their products mainly to the countries of European Union, the Balkans and the Middle East. Our findings confirm the importance of SMEs in Greece, as these firms are also the main producers of innovation. In addition our findings could be used in the development of public policy aimed at supporting and encouraging the innovation among SMEs in Greece.
\end{abstract}

Keywords: Greece, Innovation, Patents, SMEs.

\section{Introduction}

Firms need to innovate in order to maintain their competitive advantage and ensure long- term continuity. Schumpeter argued that innovation is a main source of competition among firms (Schumpeter 1942). For Schumpeter innovation comes from large corporations which are able to exploit large economies of scale in production, distribution, management and R\&D. Gradually the importance of economies of scale has reduced and the role of small firms in innovation and economic development has grown. This was the result of an increase in tastes, demands for variety and incomes. Small firms that do not embrace innovation within their core business strategy run the risk of becoming uncompetitive because of obsolete products and processes. Innovation is not just science and technology. It is also the creation of a multitude of new products and services, new marketing methods and changes in ways of organising businesses. In this framework SMEs play an important role. However, SMEs success is often dependent on the degree to which they embrace innovation. SMEs that successfully pursue innovation increase both their productivity and their likelihood of survival.

The measurement of innovation is difficult and complex. In this paper we used patent data to measure innovation in Greece and

Copyright (C) 2012 Maria Markatou. This is an open access article distributed under the Creative Commons Attribution License unported 3.0, which permits unrestricted use, distribution, and reproduction in any medium, provided that original work is properly cited. Contact author: Maria Markatou E-mail: markatou@prd.uth.gr 
more specifically all patents that have been protected in Greece during the period 1989- 2005. Patent data and statistics have been used extensively as innovation indicators for many reasons (Grupp 1990; Archibugi \& Pianta 1992). First, patents cover almost every field of technology with the only exception of software which, however, is not linked directly to the technical process and the development of products. Second, they can be used extensively, at different levels of aggregation and comparison because of the amount and detail of information they cover (Mogee 1991; Archibugi 1992). Third, patents capture those R\&D activities that are not conducted in firms, but carried out by individuals, universities and research institutions. Forth, patents include a lot of useful information (e.g. year of invention, assignee and inventor names and addresses, and citations) which is available for many years, hence can be used for numerous analyses of technology, firm, industry and country level (OECD 1994).

However, like every tool of analysis, the use of patent statistics has its own limitations. First, it has been argued that patents are not the only way to exploit firm - specific technology and hinder imitation (Pavitt 1988). Second, firms, industries and countries differ in their propensity to patent and this variance has to do, among other things, with different institutional procedures and legislation. Third, patent protection is one way to face possible competition. Other ways are the so-called "industrial secrecy" or the fast promotion and marketing of a product in the market. Firms have different attitudes in patenting and these attitudes depend on the degree of commercial exploitation of their patents and on firms' technology and marketing strategies (Mansfiled, Schwartz \& Wagner 1981). Fourth, the technological classification of patents can also be a problem. The high degree of detail and specialization, the relative difficulty in linking technology with production and the fact that a patent can by applied in many products make hard the study of patents at every level of analysis (Pavitt 1984, OECD 1994).
This is the first research that studies innovation through patents among the Greek SMEs. SMEs are very important in the OECD area, representing a major share of the total number of firms and accounting for more than the $60 \%$ of the total employment and the $50 \%$ of the total value added. The above shares are higher for Greece. The remaining sections of the paper are organized as follows: the second section presents the methodology and describes the data used. The third section examines the main features of the Greek SMEs in relation to different parameters. In section four we synthesize and further discuss the results. The fifth section contains the conclusions.

\section{Methodology and Data of Analysis}

The analysis that follows is based on the elaboration of data of a sample of 250 Greek firms. We resulted in 250 Greek firms as follows: We first constructed a patent database with all patents that have been granted by the Greek patent office during the period 1989- 2005 (5033 patents in total). We then took the patents that are owned by Greek Firms. This sample of patents contains 729 patents, which correspond to 338 Greek Firms. Taking the firm names, the surnamesnames of the owners of these patents and their addresses we first confirmed the existence of these firms, then crossexamined this data and, finally, ended up with a sample of 250 Greek firms out of 338. Based on this sample a second database was constructed with economic, production, patent and other information for these firms (46 fields of information in total).

For this analysis the Icap Economic Guide was also used. Icap is a Greek firm which, among other activities, collects data on Greek firms. Icap publishes its economic guide each year, which contains firm information on many fields. Each firm may have a maximum of 31 fields of information, such as Icap code, name, economic activity based on the ICAP taxonomy (and not based on the National Statistic Agency or Eurostat), year of 
establishment, legal status, number of employees, contact information (address, phone, fax- email), owner's name, financial data shares and countries of exports and products. However, there is missing information in many fields and this has a cost on our analysis. We used the "Economic Guide of Icap" of the years 1990, 1995, 2000 and 2005.

The data was elaborated and analyzed in two levels: the firm and the branch level. This paper aims at examining the issue of 'entrepreneurship and innovation in Greece' in relation to the SMEs. For this purpose we have studied the main features of the Greek firms with patent activities in a number of factors. We have grouped and classified our firm data based on different criteria, such as the branch- sector of activity, the products, the year of establishment, the number of employment, the export shares and its destination. The parameter of economic activities has been studied based on the NACE classification system at 2-digit, 3-digit and 4-digit code level. The examination of the parameters "year of establishment", "employment" and "export shares" is based on the creation of classes of analysis. We have created 7 classes of time period for the "year of establishment" factor: "Till 1946", "19471956", “1957- 1966”, “1967- 1976”, “19771986", "1987- 1996", "1997- today". For "employment" we have created 8 classes of analysis: "less than 20 employees", "20- 50 employees", “50- 100 employees", "100200 employees", "200- 300 employees", "300- 400 employees", "400- 500 employees" and "more than 500 employees". The analysis of "export shares" is based on the grouping of firm data according to 7 classes of analysis: "less than 5\%, "5- 10\%”, "10- 20\%”, "20-30\%”, “3040\%”, "40-50\%”, "more than 50\%”. Finally, for the two level analysis of the factor "countries of export destination" we have used classes of "geographical continent" (e.g. "America”, "Asia”, "Africa”, "Europe" and "Oceania") and classes of "geographical region" (e.g. "Balkans", "North America", "European Union" and "South- East Asia"). In most cases we have examined the above factors in time (15-20years) in order to first centre changes of major or minor importance and second coincide with the time period of the examined Greek patent activity (1989-2005).

\section{Results: Production Activities, Age, Size and Exports}

The branch distribution based on firm activities and patents shows that both the economic and the patent activity of the firms are concentrated in few economic branches and particularly in the "fabricated metal products", "machinery and equipment", "rubber and plastic products" and "chemicals and chemical products". However one main difference between the two distributions is that most of the firms are engaged in "fabricated metal products" while most of patents originate from the branch of "machinery and equipment". The "fabricated metal products" lead to metal structures, parts of structures and other metal products, such as the manufacture of builders' carpentry and joinery of metal. The branch of "machinery and equipment" ends up in the manufacture of other general and special purpose machinery, such as machinery for packaging, metal processing and waste treatment. The "rubber and plastic products" lead to the manufacture of plates, sheets, tubes and profiles. In the last important branch, the "chemicals and chemical products", a large part of the observed production concerns the manufacture of pharmaceutical preparations, toilet preparations and various agro-chemical products.

Most of the firms have been established after 1967 and before 1996. This is the dominating pattern, but with three main exceptions. The first concerns the firms that are engaged in services, which are generally younger, being established after 1987. The second exception is only related to the branch of "other non-metallic mineral products", where the $30 \%$ of the firms have been established before 1946. The third exception involves two "important" branches, namely the "fabricated metal products" and the "machinery and equipment". In these two branches the $40 \%$ of the firms have been established after 1987. 
Most of the firms need from five to thirty years after their establishment to develop a new technology and protect it through the existing patent system. This time period is shorter for the non- manufacturing firms and longer for those of the manufacturing sector. However, there is a group of 18 firms, for which this time period is very short or non-existent. We believe that, for these firms, the development of a new technology and its protection was the main cause for the beginning of a new business activity and the real motive for the establishment of a new firm.

Most firms are SMEs, employing up to 250 employees. There are no important differences between the manufacturing and the non- manufacturing firms when their respective shares are combined according to the same classes of size. The large, for the Greek standards, firms $\quad(>500$ employees) and the very small $\quad<20$ employees) concentrate the $6.02 \%$ and the $31.73 \%$ respectively. Large firms have been recorded in certain branches of the services sector (e.g. "post and telecommunications" and "health and social work"), as well as in the "basic metals". On the contrary the branches of both "wholesale and retail trade" and "machinery and equipment" are characterized by the existence of very small firms.

Based on the firm size and the patent activity of the firm and branch patent intensity were calculated. Patent intensity is larger for the firms of the manufacturing sector and is lower for the nonmanufacturing firms. "Chemicals and chemical products" are placed rather low in the total ranking, while in both "machinery and equipment" and "electrical machinery and apparatus" the patent intensity is relatively high. However, it seems that firms do not behave the same way, not even those that are classified in the same branch and are characterized by a similar size. This means that the high or low values of patent intensity are not determined by the branch of activity but by the firm itself and the decisions that will take towards this direction.

The Greek firms are characterized by different export shares and these shares range from small, medium and up to very large. Generally, the manufacturing firms export more than the non- manufacturing and this trend is more obvious in firms with at least medium export shares. The "other mining and quarrying" as well as the "machinery and equipment" contain the most export firms. On the contrary, the least export firms are those of the "food and beverages" and "chemicals and chemical products". However, firms behave differently, influenced by their own specific features and their strategies. The firms main export destinations are certain European countries (e.g. Cyprus, Germany, Italy, and United Kingdom) and the Balkans (e.g. Bulgaria, Romania, and Albany). Asia is also an important export destination (e.g. Turkey, Israel, and Saudi Arabia). A large share of the products of "other nonmetallic mineral products", "office machinery and computers" and "radio, television, communication equipment and apparatus" is directed to Asian countries. Lastly, large shares of "chemical products" and "furniture and other manufacturing products" are directed to the North African countries and Oceania respectively. 
Table 1: The Main Economic Features of the Firms with Patent Activities during the Period 1989-2005 in Greece- Analysis per Branch (2-Digit Codes)

\begin{tabular}{|c|c|c|c|c|c|}
\hline & Branches of Economic Activity & $\begin{array}{c}\text { Distribution } \\
\text { branches } \\
\text { (sample) \% }\end{array}$ & $\begin{array}{c}\text { Distribution } \\
\text { branches } \\
\text { (national) } \\
\%\end{array}$ & $\begin{array}{c}\text { Sample/ } \\
\text { National } \\
\text { Firm } \\
\text { Distribution } \\
\% \\
\end{array}$ & $\begin{array}{c}\text { Patent } \\
\text { Distribution } \\
\text { branches } \\
\text { (sample) } \\
(\%)\end{array}$ \\
\hline 1 & Food products and beverages & 6.40 & 8.16 & 1.49 & 5.64 \\
\hline 2 & Textiles & 1.20 & 2.18 & 1.05 & 0.85 \\
\hline 3 & $\begin{array}{l}\text { Tanning and dressing of } \\
\text { leather }\end{array}$ & 0.40 & 0.56 & 1.35 & 0.17 \\
\hline 4 & $\begin{array}{l}\text { Wood, products of wood and } \\
\text { cork }\end{array}$ & 0.80 & 0.89 & 1.71 & 0.85 \\
\hline 5 & $\begin{array}{l}\text { Pulp, paper and paper } \\
\text { products }\end{array}$ & 3.20 & 0.93 & 6.56 & 2.91 \\
\hline 6 & $\begin{array}{l}\text { Publishing, printing, } \\
\text { reproduction of media }\end{array}$ & 0.40 & 3.36 & 0.23 & 0.51 \\
\hline 7 & Chemical products & 8.80 & 2.11 & 7.94 & 10.26 \\
\hline 8 & Rubber and plastic products & 9.60 & 2.11 & 8.66 & 9.74 \\
\hline 9 & $\begin{array}{l}\text { Other non-metallic mineral } \\
\text { products }\end{array}$ & 2.80 & 3.43 & 1.55 & 2.39 \\
\hline 10 & Basic metals & 5.60 & 0.72 & 14.74 & 3.59 \\
\hline 11 & Fabricated metal products & 16.40 & 3.08 & 10.12 & 15.56 \\
\hline 12 & Machinery and equipment & 13.60 & 1.92 & 13.44 & 18.8 \\
\hline 13 & $\begin{array}{l}\text { Electrical machinery and } \\
\text { apparatus }\end{array}$ & 5.20 & 0.88 & 11.21 & 8.21 \\
\hline 14 & $\begin{array}{l}\text { Radio and television } \\
\text { communication equipment }\end{array}$ & 1.60 & 0.21 & 14.29 & 3.08 \\
\hline 15 & $\begin{array}{l}\text { Medical, precision and optical } \\
\text { instruments }\end{array}$ & 0.40 & 0.31 & 2.44 & 0.68 \\
\hline 16 & $\begin{array}{l}\text { Motor vehicles, trailers and } \\
\text { semi- trailers }\end{array}$ & 1.20 & 0.26 & 8.82 & 0.85 \\
\hline 17 & Other transport equipment & 0.40 & 0.43 & 1.75 & 0.17 \\
\hline \multirow[t]{2}{*}{18} & Furniture; Manufacturing & 5.20 & 2.20 & 4.48 & 4.27 \\
\hline & Total manufacture & 83.20 & 33.74 & 4.69 & 88.55 \\
\hline 19 & $\begin{array}{l}\text { Agriculture, animal husbandry, } \\
\text { hunting }\end{array}$ & 0.40 & 1.57 & 0.48 & 0.85 \\
\hline 20 & Other mining and quarrying & 1.60 & 0.74 & 4.12 & 0.68 \\
\hline 21 & Construction & 0.40 & 9.97 & 0.08 & 0.17 \\
\hline 22 & $\begin{array}{l}\text { Wholesale and commission } \\
\text { trade }\end{array}$ & 7.60 & 35.42 & 0.41 & 5.64 \\
\hline 23 & Retail trade & 0.40 & 9.27 & 0.08 & 0.17 \\
\hline 24 & Post and telecommunications & 0.40 & 0.80 & 0.95 & 0.34 \\
\hline 25 & $\begin{array}{l}\text { Renting of machinery and } \\
\text { equipment }\end{array}$ & 0.40 & 1.73 & 0.44 & 0.17 \\
\hline 26 & $\begin{array}{l}\text { Computer and related } \\
\text { activities }\end{array}$ & 3.20 & 3.08 & 1.98 & 2.05 \\
\hline 27 & Other business activities & 2.00 & 1.62 & 2.35 & 1.2 \\
\hline \multirow[t]{3}{*}{28} & Health and social work & 0.40 & 2.06 & 0.37 & 0.17 \\
\hline & Total rest branches & 16.80 & 66.26 & 0.48 & 11.45 \\
\hline & Total branches of economy & 100.00 & 100.00 & 1.90 & 100 \\
\hline
\end{tabular}


Table 2: The Main Economic Features of the Firms with Patent Activities during the Period 1989-2005 in Greece- Analysis per Branch (2-Digit Codes)

\begin{tabular}{|c|c|c|c|c|c|c|}
\hline & $\begin{array}{l}\text { Year of } \\
\text { Establishment } \\
\text { (period) }\end{array}$ & $\begin{array}{l}\text { Time between } \\
\text { establishment } \\
\text { and first } \\
\text { patent }\end{array}$ & $\begin{array}{l}\text { Employment } \\
\text { (classes) }\end{array}$ & $\begin{array}{l}\text { Patent } \\
\text { Intensity } \\
\text { (mean, } \\
\text { branch) }\end{array}$ & $\begin{array}{l}\text { Export } \\
\text { Shares } \\
\text { (classes) }\end{array}$ & $\begin{array}{l}\text { Direction of } \\
\text { exports } \\
\text { (regions) }\end{array}$ \\
\hline 1 & $2^{n}-3^{\text {rd }}$ period & 29.31 & Small & 0.050 & Medium & Eur. Union \\
\hline 2 & $3^{\text {rd }}$ period & 15.33 & Small & 0.052 & Medium & Eur. Union \\
\hline 3 & $3^{\text {rd }}$ period & 7 & Small & & Medium & Eur. Union \\
\hline 4 & $2^{\text {nd }}$ period & 23.5 & Very small & 0.190 & Medium & Balkans \\
\hline 5 & $3^{\text {rd }}$ period & 15.12 & $\begin{array}{l}\text { Small- } \\
\text { Medium }\end{array}$ & 0.017 & Medium & $\begin{array}{l}\text { European } \\
\text { Union }\end{array}$ \\
\hline 6 & $2 \eta$ period & 20 & Small & & Medium & Europe \\
\hline 7 & $2^{\text {nd }}$ period & 25.81 & $\begin{array}{l}\text { Small- } \\
\text { Medium }\end{array}$ & 0.040 & Medium & $\begin{array}{l}\text { Balkans-Eur. } \\
\text { Union }\end{array}$ \\
\hline 8 & $2^{\text {nd }}-3^{\text {rd }}$ period & 18 & $\begin{array}{l}\text { Small- } \\
\text { Medium }\end{array}$ & 0.071 & Medium & $\begin{array}{l}\text { Balkans-Eur. } \\
\text { Union }\end{array}$ \\
\hline 9 & $3^{\text {rd }}$ period & 26.42 & Small & 0.038 & Medium & $\begin{array}{l}\text { Balkans-Eur. } \\
\text { Union }\end{array}$ \\
\hline 10 & $2^{\text {nd }}-3^{\text {rd }}$ period & 19.64 & & 0.072 & Medium & $\begin{array}{l}\text { Balkans-Eur. } \\
\text { Union }\end{array}$ \\
\hline 11 & $2^{\text {nd }}-3^{\text {rd }}$ period & 18.073 & Small & 0.080 & Medium & $\begin{array}{l}\text { Balkans-Eur. } \\
\text { Union }\end{array}$ \\
\hline 12 & $3^{\text {rd }}-4^{\text {th }}$ period & 17.47 & Small & 0.176 & Medium & Eur. Union \\
\hline 13 & $3^{\text {rd }}-4^{\text {th }}$ period & 17.84 & Small & 0.169 & Medium & $\begin{array}{l}\text { Balkans-Eur. } \\
\text { Union }\end{array}$ \\
\hline 14 & $2^{\text {nd }}-3^{\text {rd }}$ period & 16.75 & Large & 0.080 & Medium & Eur. Union \\
\hline 15 & $3^{\text {rd }}$ period & 10 & Very small & & High & Eur. Union \\
\hline 16 & $2^{\text {rd }} \& 3^{\text {rd }}$ period & 16.33 & Very small & 0.271 & & $\begin{array}{l}\text { South-East } \\
\text { Asia }\end{array}$ \\
\hline 17 & $4^{\text {rd }}$ period & 3 & Very small & & & Balkans \\
\hline \multirow[t]{2}{*}{18} & $3^{\text {rd }}$ period & 14.23 & Small & 0.062 & Medium & $\begin{array}{l}\text { Balkans-Eur. } \\
\text { Union }\end{array}$ \\
\hline & & 17.43 & & 0.102 & Medium & $\begin{array}{l}\text { Balkans-Eur. } \\
\text { Union }\end{array}$ \\
\hline 19 & $3^{\text {rd }}$ period & 20 & Medium & & Low & $\begin{array}{l}\text { Balkans-Eur. } \\
\text { Union }\end{array}$ \\
\hline 20 & $1^{\text {st }} 2^{\text {nd }}$ period & 31.25 & Very Small & 0.042 & High & Eur. Union \\
\hline 21 & $3^{\text {rd }}$ period & 9 & Small & & & \\
\hline 22 & $3^{\text {rd }}$ period & 13.63 & Very small & 0.195 & Low & $\begin{array}{l}\text { Balkans-Eur. } \\
\text { Union }\end{array}$ \\
\hline 23 & $3^{\text {rd }}$ period & 7 & Very small & & & Balkans \\
\hline 24 & $1^{\text {st }}$ period & 42 & Very large & & & \\
\hline 25 & $3^{\text {rd }}$ period & 12 & Very small & & & \\
\hline 26 & $3^{\text {rd }}$ period & 10.62 & $\begin{array}{l}\text { Small- } \\
\text { Medium }\end{array}$ & 0.072 & Medium & $\begin{array}{l}\text { Balkans-Eur. } \\
\text { Union }\end{array}$ \\
\hline 27 & $3^{\text {rd }}-4^{\text {th }}$ period & 6.4 & Small & 0.0362 & Low & $\begin{array}{l}\text { Balkans-Eur. } \\
\text { Union }\end{array}$ \\
\hline \multirow[t]{3}{*}{28} & $3^{\text {rd }}-4^{\text {th }}$ period & 9 & Very large & & & \\
\hline & & 16.09 & & 0.066 & & $\begin{array}{l}\text { Balkans-Eur. } \\
\text { Union }\end{array}$ \\
\hline & & 16.76 & & 0.08 & & $\begin{array}{l}\text { Balkans-Eur. } \\
\text { Union }\end{array}$ \\
\hline
\end{tabular}




\section{Synthesis of Results- Discussion}

The results confirm the importance of SMEs in the development of innovation in Greece. The results are also similar with those of other Greek studies and reports. The only relevant and available report so far is the GSRT report (2001). GSRT is the official government body for science and technology in Greece, and the report referred to has studied several aspects of the innovativeness of the Greek firms. The similarities are obvious: First, the GSRT report has found that "machinery and equipment", "electrical machinery and apparatus", "radio, television and communication equipment and apparatus" and "fabricated metal products" are the most innovative branches. On the contrary the branch of "food and beverages", although it is the most important in Greece based on its total number of firms, exhibits relatively small innovation activity (6.2\%). This means that four out of five branches are the same between our analysis and the GSRT report. In this study, the branch of "food and beverages" performs in a similar way, capturing $6.4 \%$ of firms and $5.64 \%$ of patents during the period 1989-2005. Second, the analysis shows that the small firms are the main owners of the granted patents in Greece. So firms that employ up to 50 employees account for $57.83 \%$ of our sample. This result is also similar with the GSRT result, where $56 \%$ of firms employ up to 50 employees, while the very large firms (more than 500 employees) exhibit low innovation activity, accounting only for $7.2 \%$. In the present analysis the share of very large firms is $6.02 \%$. However, if we take into consideration only the firms of the manufacturing sector, then the very small firms ("less than 20 employees") represent $29.32 \%$ of the sample, the class (20- 50 employees) $27.40 \%$ and the class "more than 500 employees" $5.76 \%$. Therefore, the very small and small firms are the main owners of patents and the main innovators in Greece, while firms with a medium size follow.

Our results concern a sample of 250 firms. How can these results be compared with the respective national pattern? In table 1 we present the total- national branch distribution based on the ICAP database (column 4) and compare it with our branch distribution (column 3). What can be seen is that the firms of the above "important" branches account for $56 \%$ of the sample and the $44.44 \%$ of the national total. If, however, we do not consider the share of "wholesale" (5 $5^{\text {th }}$ most important branch in our sample), then the $48 \%$ of the Greek firms and the $54.36 \%$ of their patents (columns 3 and 6) are only related with the $9.22 \%$ of the Greek firms (column 3). The "wholesale trade" is a very important branch, accounting for $7.6 \%$ in the sample and $35.42 \%$ in the respective national total. In addition, if we also take into consideration the relative weight of our branches, then our initial taxonomy differentiates (column 5). With the new taxonomy the most important branches are the following: "Basic metals", "radio, television, communication equipment and apparatus", "machinery and equipment", "electrical machinery and apparatus" and "fabricated metal products".

The results show the importance of certain economic branches in the development of innovation in Greece. However, are these branches characterized by fast, medium or low growth rates? In table 3 the development trends of the Greek manufacturing branches are presented based on the SEV (Greek Industry Association) Report (2003). In total, ten branches have been characterized by fast growth during the period 1995- 2003. Among these branches are three, which are classified in our top positions based on our results: "Chemicals and chemical products", "rubber and plastic products" and "fabricated metal products". The 35\% of firms and their patents are classified in these three branches based on our analysis. The second most important branch (based on the total number of firms) and the first most important branch (based on the number of patents) is a "medium growth" branch (e.g. "machinery and equipment"). On the contrary, the declining branches during the period 1995- 2003, are those with low and very low shares of patents and firms based on our analysis. Concluding, in the "fast growth" branches are concentrated the $49.2 \%$ of firms and 
the $52 \%$ of patents. In the "medium growth" branches the $28 \%$ of firms and the $31.31 \%$ of patents are recorded, while only the $5.6 \%$ of firms and the $4.78 \%$ of patents are related to the declining branches. This means that half of the firms and of the patents originate from "important" branches, namely branches of "fast growth" and high indexes of production.

Table 3: Trends and Prospects in the Branches of Manufacturing, Classification of Branches Based On Their Technology Level and Exports in Greece and in OECD Countries

\begin{tabular}{|c|c|c|c|c|c|}
\hline $\begin{array}{l}\text { Branches of economic } \\
\text { activity }\end{array}$ & $\begin{array}{l}\text { Weighted } \\
\text { index }\end{array}$ & $\begin{array}{c}\text { Share of } \\
\text { production } \\
\text { level- } \\
\text { Production } \\
\text { indexes 2003 }\end{array}$ & $\begin{array}{l}\text { Taxonomy of the } \\
\text { branches based on their } \\
\text { technology level }{ }^{1}\end{array}$ & $\begin{array}{l}\text { Share of } \\
\text { firms and } \\
\text { patents } \\
\text { (our } \\
\text { results) }\end{array}$ & $\begin{array}{l}\text { Export shares } \\
\text { for Greece and } \\
\text { OECD }\end{array}$ \\
\hline \multicolumn{6}{|c|}{ Branches-fast growth rates (1995- 2003) } \\
\hline Motor vehicles- trailers & 0.59 & $141.41-41.4$ & $\begin{array}{l}\text { Medium- high } \\
\text { technology }\end{array}$ & $1.2-0.85$ & $1.5-14.5$ \\
\hline $\begin{array}{l}\text { Chemicals- chemical } \\
\text { products }\end{array}$ & 8.47 & $66.02-166$ & $\begin{array}{l}\text { High, Medium- high } \\
\text { technology }\end{array}$ & 8.8- 10.2 & $9.7-12.8$ \\
\hline $\begin{array}{l}\text { Medical, precision, optical } \\
\text { instruments }\end{array}$ & 0.35 & $54.24-154.2$ & High technology & $0.4-0.17$ & $0.8-4.4$ \\
\hline Publishing, printing & 3.44 & 48.76- 148.8 & Low technology & $0.4-0.51$ & $0.8-2.6^{2}$ \\
\hline Fabricated products & 4.14 & 41.10- 141.1 & $\begin{array}{l}\text { Medium- low } \\
\text { technology }\end{array}$ & 16.4- 15.5 & $14.6-7.1^{3}$ \\
\hline $\begin{array}{l}\text { Coke, refined petroleum } \\
\text { products }\end{array}$ & 4.58 & 35.91- 135.9 & $\begin{array}{l}\text { Medium- low } \\
\text { technology }\end{array}$ & & 12.5- 2.1 \\
\hline Basic metals & 7.38 & $34.72-134.7$ & $\begin{array}{l}\text { Medium- low } \\
\text { technology }\end{array}$ & $5.6-3.59$ & $14.6-7.1^{3}$ \\
\hline Rubber, plastic products & 4.28 & $34.69-134.7$ & $\begin{array}{l}\text { Medium- low } \\
\text { technology }\end{array}$ & $9.60-9.74$ & 3.3- 2.7 \\
\hline $\begin{array}{l}\text { Radio, television, com. } \\
\text { equipment }\end{array}$ & 1.61 & $27.42-127.4$ & High technology & $1.6-3.08$ & $3.1-8.6$ \\
\hline $\begin{array}{l}\text { Electrical machinery and } \\
\text { apparatus }\end{array}$ & 2.45 & 25.93- 125.9 & $\begin{array}{l}\text { Medium- high } \\
\text { technology }\end{array}$ & $5.2-8.21$ & $2.9-5$ \\
\hline \multicolumn{6}{|c|}{ Branches-medium growth rates (1995- 2003) } \\
\hline $\begin{array}{l}\text { Other non-metallic } \\
\text { mineral products }\end{array}$ & 6.84 & $23.93-123.9$ & $\begin{array}{l}\text { Medium- low } \\
\text { technology }\end{array}$ & $2.8-2.39$ & $3.8-1.5$ \\
\hline Food products, beverages & 22.48 & 17.86- 117.9 & Low technology & $6.4-5.64$ & $16.6-6^{4}$ \\
\hline Machinery and equipment & 3.29 & $17.25-117.3$ & $\begin{array}{l}\text { Medium- high } \\
\text { technology }\end{array}$ & 13.6- 18.8 & 4.4- 11.5 \\
\hline Furniture; Rest Man. & 1.97 & $13.36-113.4$ & Low technology & $5.2-4.27$ & $1.2-2.9^{5}$ \\
\hline Recycling & 0.05 & 5.62 & Low technology & & $1.2-2.9^{5}$ \\
\hline \multicolumn{6}{|c|}{ Declining branches (1995- 2003) } \\
\hline Pulp- paper products & 3.63 & $-7.07-92.9$ & Low technology & $3.2-2.91$ & $0.8-2.6^{2}$ \\
\hline Tobacco products & 1.94 & $-11.01-89$ & Low technology & & $16.6-6^{4}$ \\
\hline Textiles & 8.12 & $-15.76-84.2$ & Low technology & $1.2-0.85$ & $21.2-5.1^{6}$ \\
\hline Wearing apparel, dressing & 6.43 & $-21.00-79$ & Low technology & & $21.2-5.1^{6}$ \\
\hline $\begin{array}{l}\text { Wood, products of wood } \\
\text { and cork }\end{array}$ & 1.35 & $-23.74-56.8$ & Low technology & $0.8-0.85$ & $0.8-2.6^{2}$ \\
\hline $\begin{array}{l}\text { Other transport } \\
\text { equipment }\end{array}$ & 5.06 & $-30.11-69.9$ & $\begin{array}{l}\text { High, Medium- low, } \\
\text { Medium- high } \\
\text { technology }\end{array}$ & & $1.3-5.7$ \\
\hline Leather & 1.49 & $-43.21-56.8$ & Low technology & $0.4-0.17$ & $21.2-5.1^{6}$ \\
\hline $\begin{array}{l}\text { Office machinery and } \\
\text { computers }\end{array}$ & 0.07 & $-71.71-28.3$ & High technology & & $0.9-5.5$ \\
\hline
\end{tabular}


Let us now link our branches with the factors of technology and export shares. The branches of "fast growth" are both "high- medium technology" and "mediumlow technology" branches. On the contrary, in the branches of both "medium growth rates" and the declining branches the "low technology" class dominates. In total, only $2 \%$ of firms, $3.25 \%$ of patents and $4.8 \%$ of exports are related to branches of "high technology". In OECD countries the share of exports in branches of "high technology" accounts for $18.5 \%$. In "high- medium technology" branches, the above shares are 28.8\% (number of firms), 38.12\% (number of patents) and $19.8 \%$ (export shares) based on our sample. The respective export share for all OECD countries is $49.5 \%$. In the branches of "medium- low technology" we can record $34.4 \%$ of firms, $31.28 \%$ of patents and $34.2 \%$ of exports. The respective export share for all OECD countries is $13.4 \%$. Finally, the above shares are $17.6 \%$ (number of firms), $15.2 \%$ (number of patents) and $39.85 \%$ (export shares) for the branches classified in the "low technology" class. The respective export share for all OECD countries is $16.65 \%$. Therefore, $63.2 \%$ of firms with patent activities during the period 19892005 are engaged in economic activities of "medium- high" and "medium- low" technology. In the first activities the Greek exports are much lower that the respective OECD average. In the last activities it can be pointed out the opposite (e.g. the Greek exports are much higher than the respective OECD average). At the same time the shares of firms, patents and exports in the activities of "high technology" are very low based on our sample, while there is an important rest $17.6 \%$ share of firms. This share contains firms with "low technology" activities, but with very important export shares. Concluding, the Greek firms with patent activities during the period of 1989-2005 originate from economic branches with "fast" and mainly "medium" levels of economic growth. However, these branches are also characterized as "medium- low" and "low" technology branches, the products of which account for $75 \%$ of the total Greek exports.

\section{Conclusions}

SMEs are very important in the development and the production of innovation in Greece. The examination of their features shows that most of them have been established during the period 1967-1996 and are characterized by different levels of exports, selling their products to the countries of European Union and the Balkans. A large part of Greek firms combines its manufacturing with its commercial activities. Almost 50\% of these firms and more than $50 \%$ of their total patent activity are concentrated in four manufacturing branches and more specifically in the "fabricated metal products", "machinery and equipment", "chemicals and chemical products" and "rubber and plastic products".

Examining carefully firm production activities and the related products we can focus on four points: First, a large part of these production activities is directly and indirectly related to the so- called "construction industries". These industries have a long history and tradition in Greece. Second, the case of "fertilizers, nitrogen compounds, pesticides and other agrochemical products" is obviously related to the agricultural sector, which is, in any case, very important in Greece. The third production and specialization trend concerns the pharmaceutical preparations. This case is different, meaning that it is well known that the majority of chemical products and particularly pharmaceuticals are mainly protected by patent laws and its system. Four, there is a group of forty two firms which develop patents, although these firms are non- manufacturing. The economic activities of these firms are related to the branches of agriculture, mining, wholesale and services. We believe that this result needs further examination, meaning that there is an obvious question: How can this non- manufacturing patent activity can be explained? Is it a matter of creativity from isolated employees or selfemployed businessmen that is expressed this way and is finally certified by the granting of one or more patents? 
Is it the personal interest or desire of some people? Is it a conscious business choice and perhaps an economic transition from non- manufacturing to manufacturing activities? We suggest that further research should be executed on this field.

\section{References}

Archibugi, D. (1992). "Patenting as an Indicator of Technological Innovation: A Review," Science and Public Policy, 19 (6), 357-368.

Archibugi, D. \& Pianta, M. (1992). The Technological Specialization of Advanced Countries, a Report to the EEC on International Science and Technology Activities, Kluwer Academic Publishers, Dordrecht.

Grupp, H. (1990). 'Technometrics as a Missing Link in Science and Technology Indicators,' In: Measuring the Dynamics of Technological Change, Sigurdson J. (Ed), Pinter, London.

GSRT. (2001). Study of the Innovativeness of the Greek Firms, GSRT, Athens (In Greek).

Mansfield, E., Schwartz, M. \& Wagner, S. (1981). "Imitation Costs and Patents: En Empirical Study," The Economic Journal, 91, 907-918.

Mogee, M. E. (1991). 'Using Patent Data for Technology Analysis and Planning,' Research Technology Management, 34 (4), 43-49.

OBI Special Bulletins of Industrial Property, Years: 1989- 2005, OBI, Athens (In Greek).

OECD. (1994). OECD Patent Manual, OECD, Paris.

OECD. (2005). OECD Factbook for Years 2005 and 2006, OECD, Paris.

Pavitt, K. (1984). "Sectoral Patterns of Technological Change. Towards a Taxonomy and a Theory," Research Policy, 13, 343-365.
Pavitt, K. (1988). 'Uses and Abuses of Patent Statistics,' In: Handbook of Quantitative Studies of Science and Technology, Raan, AGJ. (Ed), North Holland, Amsterdam.

Schumpeter, J. A. (1934). "The Theory of Economic Development: An Inquiry into Profits, Capital, Credit, Interest, and the Business Cycle," Harvard University Press, Cambridge, Mass.

SEV. (2003). The Greek Economy (2003), SEV, Athens (In Greek). 